\title{
Enhancing Societal Wellbeing and Wealth Creation -Sewing Skills Programmed For Rural Housewives in Sabah
}

\author{
Abdul Rahman Ahmad Dahlan, Nurul Syafikha Jaafar, Noor Shuhada Binti Che \\ Hassan, Siti Syafikah Sheikh Kamaruzzaman, Uzma Iqbal \\ Kulliyyah of Information \& Communication Technology, International Islamic University Malaysia (IIUM)
}

\begin{abstract}
This paper proposes eSisterApparel Program and to be adopted as one of the 1AZAM Malaysian government-sponsored programs, raising the economic and social status of women especially of rural housewives in Sabah, Malaysia. This program has the potential to reduce poverty by providing these housewives with sewing skills, sewing machines, and eSisterApparel Portal in generating new sources of income. Sabah, a state in East Malaysia, has the highest level of poverty and hardcore poverty incidence in Malaysia. Literature reviews and nine (9) blocks of Business Model Canvas (BMC) framework are used as methodology for this paper. As the extent of rural poverty in Sabah is expected to be reduced and societal wellbeing to be enhanced through eSisterApparel Program, an added benefit is the minimization of the rural-urban migration process. This in turn will result in less pressure on government to make provision for additional spending on services such as education, provision of clean drinking water and adequate sewage disposal, housing, and health in urban areas as well as having to deal with a host of problems associated with overgrown cities and towns such as a higher incidence of crime and of shanty towns on the outskirts of these cities.
\end{abstract}

Keywords: Societal wellbeing, Wealth creation, ICT, Sabah, Housewives, BMC, IAZAM

\section{Introduction}

In Malaysia, poverty eradication has been the focus and primal priority of the Government (Sohag, 2005; Habiba et. al, 2013) where policies, initiatives and programs such as the New Economic Policy (NEP) was introduced and implemented starting in 1970. The poverty eradication programs have resulted in drastic reduction in poverty and lessened the income inequality while achieving rapid economic growth and maintaining racial harmony. The NEP from 1970 to 1990 and subsequent policies have markedly reduced poverty in Malaysia, where poverty headcount ratio at national poverty line in Malaysia is reported as follows $3.8 \%$ in $2009,3.6 \%$ in 2007, $5.7 \%$ in 2004, $15.5 \%$ in 1989 (World Bank, 2013). In terms of poverty by state in Malaysia, Sabah has the highest level of poverty and hardcore poverty incidence in Malaysia (EPU, 2012).

The issue of poverty reduction has moved to the next crucial level as the Malaysian government's target is to achieve a high income country by 2020. The eKasih or Sistem Maklumat Kemiskinan Negara is a database system which contains the information of the poor family in Malaysia. The objective of the database system is to help the government in planning, implementing and monitoring the "Poverty Eradication" programs. As at 14 January 2011, there were 67,033 (0.82\%) households registered as poor in the eKasih database (Habiba et. al, 2013). The information from eKasih will be used as a base for providing aids or projects' involvement in 1AZAM, another government "Poverty Eradication" program, programmed for the poor families. 1AZAM is a key program supported by the Malaysian government, spearheaded by the Ministry of Women, Family and Community Development. 1AZAM stands for "Akhiri Zaman Miskin" in Malay word, but in English is to eradicate poverty, where its main objective is to help the poor citizens with an income of RM830 per month and low-income citizens under RM2, 300 a month generating better income.

\section{Project Background}

This paper proposes eSisterApparel Program, to be adopted or adapted as one of the 1AZAM Malaysian government-sponsored programs in raising the economic and social status of women especially of rural housewives in Sabah, Malaysia. This program has the potential to reduce poverty and enhance societal wellbeing by providing these housewives with sewing skills and sewing machines to produce cheap but yet elegant clothes for Muslim women, and promoting and selling these clothes through eSisterApparel Portal in generating new sources of income. The 1Azam provides opportunity for poor families to enhance societal wellbeing in generating income via giving them opportunity in four areas, namely: (1) Azam Kerja for opportunity to generate income through work placement, (2) Azam Tani to generate income based on agriculture, (3) Azam Niaga to generate income through small business, and (4) Azam Khidmat to generate income through services (Ministry of Women, Family and Community Development, 2012). 
The current and future trend is for people to conduct daily on-line transactions including shopping. Based on the mega-trend study by Frost \& Sullivan (2012), there is a major shift from "Connecting Subscribers to Connecting Devices", where there will be 80 billion of devices are connected by 2020 . By 2025, the majority of the world's population will have access to all of the world's content through a device that fits in the palm of the hand. If the current pace of technological innovation is maintained, most of the projected eight billion people on Earth will be online (Eric Schmidt and Jared Cohen, 2013).

eSisterApparel Program provides services to help the rural housewives in Sabah. The services provided by this Program include motivation and advisory, training on sewing skills, and applying sewing machines from the government. The sewing machines are sponsored by the government through Azam Niaga in generating sustainable income through small business. In addition, there will be tutorial workshop from experience tailors and assistants from the IIUM Student Sewing Club. Workshop is conducted free-of-charge for two (2) weeks, and after that these housewife are ready to promote and market their sewing skills through online eSisterApparel Portal. Clothes shall be made only after receiving order by customers through the Portal. Customers will choose the types and designs, as well as providing measurement or size of their clothes. The sales of the clothes will be an additional source of income for the housewives as well as to be used as capital in sustaining their business operations.

\section{Project Objectives}

The main objective of eSisterApparel Program is to harness on Malaysian government-sponsored poverty eradication program, namely 1AZAM that leverages on eKasih database that is spearheaded by the Ministry of Women, Family and Community Development (MWFCD). This Program has the potentialto reduce poverty by providing these housewives with sewing skills, sewing machines, and eSisterApparel Portal in generating new sources of income. Sabah, a state in East Malaysia, with the highest level of poverty and hardcore poverty incidences in Malaysia is chosen for this proposed eSisterApparel Program implementation.

As the extent of rural poverty in Sabah is expected to be reduced and societal wellbeing to be further enhanced through eSisterApparel Program, an added benefit is the minimization of the rural-urban migration process. This in turn will result in less pressure on government to make provision for additional spending on services such as education, provision of clean drinking water and adequate sewage disposal, housing, and health in urban areas as well as having to deal with a host of problems associated with overgrown cities and towns such as a higher incidence of crime and of shanty towns on the outskirts of these cities. At the same time, there is a need for a change management program (Ammy Amelia Faisal et. al, 2013; Cutifa Safitri et. al, 2013; Fatima Munassar et. al, 2013) to make eSisterApparel Program a success. According to (Alyaa Ghani et. al, 2013), "Change is a critical issue that needs a proper management to handle it effectively".

\section{Literature Review}

1AZAM program was introduced to eradicate and reduce poverty rate in Malaysia by providing employment and/or entrepreneurship to the nation's hardcore poor and poor citizens. "The concept of entrepreneurship as defined by Casson (1985) is the management of resources which is essential in controlling wealth, not unlimited resources controlling wealth" (Prof. Dr. Mohd. Taib Hj. Dora, 2011). This 1AZAM program aims to increase income generation, exceeding the poverty limits of RM830 per month for the poor and under RM2, 300 a month for low-income earners. 1AZAM is being conducted nationwide in stages. The pilot program was initiated in the Iskandar Regional Development Authority (IRDA) or Iskandar Malaysia, Johor, at the end of January 2010.

Based on The New Straits Times (NST) dated 14 June 2012, the Prime Minister Datuk Seri Najib Tun Razak has said that the involvement of 80,579 people in the 1Azam programme shows its effectiveness as a strategic effort by the government to eradicate poverty. (NST, 14/6/2012.PM: 1Azam programme effective in eradicating poverty.) This statement has been supported by the publication of NST on 24 September 2013 stating that the 1Azam programme had recorded a reduction of 55.3 per cent of the national poverty rate, according to the Women, Family and Community Development Minister, Datuk Rohani Abdul Karim. Sources from the Asian Development Bank (ADB) conference said the national poverty rate has dropped from 3.8 per cent in 2009 to 1.7 per cent in 2012. (NST, 24/9/2013. 1Azam records 55.3\% cut in national poverty rate.)

NST dated 13 September 2013; Women, Family \& Community Development Minister said that from 2010 until the end of last year, 65.65 per cent of the 106,967 1Azam programme participants comprised women. The 1AZAM programme has so far trained and created 4,300 women entrepreneurs, with 86.86 per cent of them comprising Bumiputera (NST, 13/9/2013. 1Azam programme has created 4,300 women entrepreneurs). However, at the global scenario women make up the majority of illiterates in the world, have less access to economic resources, and have little free time because they shoulder the majority of household responsibilities. Women face greater challenges to IT access and education. Unless women and marginalized populations 
participate fully in IT, they risk missing significant opportunities for economic, political and social empowerment that IT can facilitate (Malathi Subramanian, 2007).

The current and future trend is for people to conduct daily on-line transactions including shopping. Based on the mega-trend study by Frost \& Sullivan (2012), there is a major shift from "Connecting Subscribers to Connecting Devices", where there will be 80 billion of devices are connected by 2020 . By 2025, the majority of the world's population will have access to all of the world's content through a device that fits in the palm of the hand. According to Eric Schmidt and Jared Cohen (2013), if the current pace of technological innovation is maintained, most of the projected eight billion people on Earth will be online including in the developing countries. Through Internet, age old limitations to human interaction, like geography, language, and limited \& controlled information, are falling and a new wave of human creativity, innovation and potential is rising. Mass adoption of the Internet is driving one of the most exciting social, cultural and political transformations in history, and unlike earlier periods of change, this time the effects are fully global (Eric Schmidt and Jared Cohen, 2013). Never before in history have so many people, from so many places, had so much power at their fingertips. And while this is hardly the first technology revolution in our history, it is the first that will make it possible for almost everybody to own, develop and disseminate real-time content without having to rely on intermediaries.

\section{Conceptual solution}

In focusing to eSisterApparel Portal, it will make use of the Internet to provide a user-friendly, engaging and attractive portal with many useful functionality and features. "The Internet is a technology that they use to communicate, collaborate, and share databases, information and knowledge in creating values and improve societal well-being" (Burhan Saleh et. al, 2013). It will include usability and navigation, usable form, secondary call-to action, social button and contact info. Customer can books a cloth on tailoring by completing the provided usable form on our website. All needed information and customer details will be included in the usable form. This Portal will provide samples of unsewn fabrics that are available on KAMDAR Fabric Company. When a customer clicks on the sample's picture, the secondary call-to-action button will appear that provides the customer details about the fabrics such as price and availability. Hence, the customer does not have to give the fabric by hand to the tailor just like the traditional tailoring. It is also saving the customer delivering fees because she does not have to post their own fabric to the tailor just like the current e-tailor such as Kedai JahitKu. In order to protect the tailor rights, the customer need to pay some advances to avoid the customer from cancelling their order and to be used in buying their chosen unsewn fabric.

As part of advertisement, eSisterApparel Portal shall embed social network buttons such as Facebook and Twitter. Hence, customers can share eSisterApparel Portal in their social network. In order to attract more on-line visitors, eSisterApparel Portal shall be linked to other popular blogs, portals and websites. eSisterApparel Portal has advantages over the traditional tailoring businesses, namely in terms of global reach and wider range of customers. For the existing e-tailor businesses, eSisterApparel Portal provides a better service by providing many choice of unsewn fabric, saving customers' time for buying the fabrics as well as lower delivering costs. In addition, eSisterApparel Portal provides a free membership and platform for the Community of Practice (CoP) in sewing.

Figure 1 shows the 9 blocks of Business Canvas Model (BMC) of Sewing Skills Programmed for Housewives in Sabah. The 9 blocks of BMC are customer segment, customer relationship, channel, value proposition, key activities, key resources, key partners, course structure and revenue streams which based on Alexander Osterwalder (2010).

\section{Customer segment}

There are two focus customer segments. The first customer segment is housewives with sewing skills from poor as well as well-to-do families. The second segment is the on-line shoppers. Initially, the focus is on Muslim women customers from Malaysia because eSisterApparel Portal sell Muslim women clothes. 


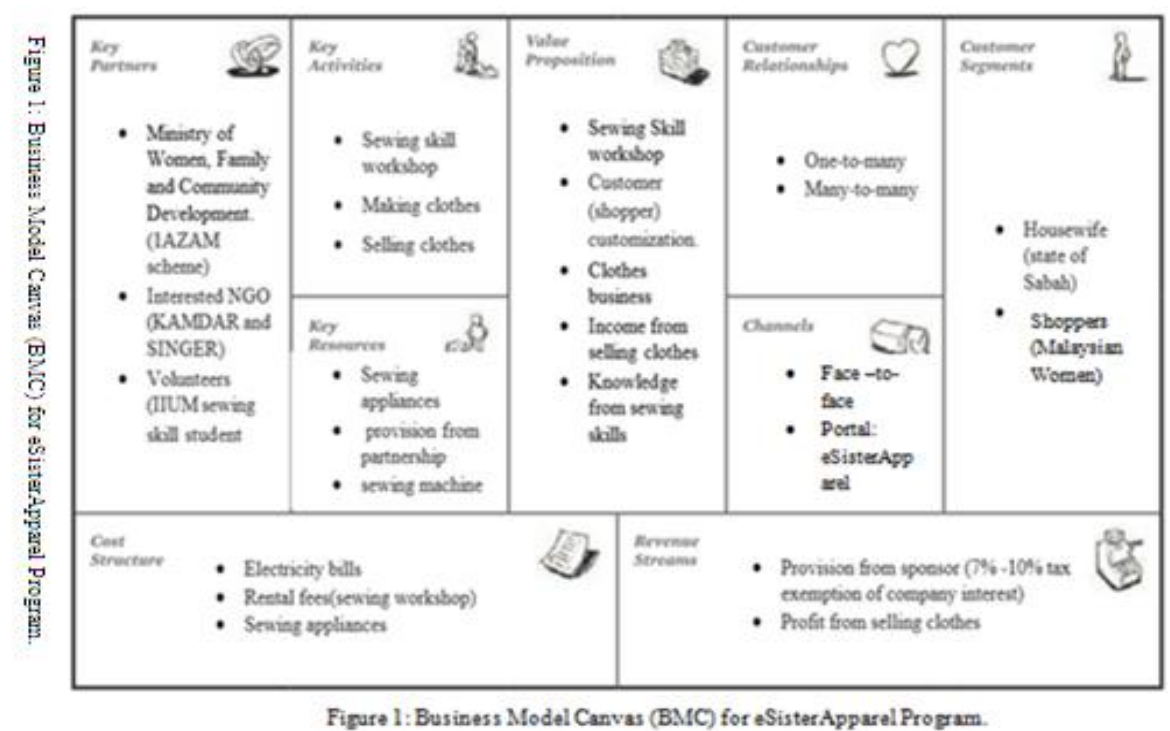

\section{Customer Relationship}

There are two types of customer relationships. One is where a tutor is conducting sewing workshops for housewives physically as well as virtually. The other relationship is selling and buying clothes through eSisterApparel Portal.

\section{Channel}

eSisterApparel Portal ainjgs.wix.com/sistersapparel as shown in Figure 2 is an attractive, engaging, and user-friendly website incorporating social network buttons such as Facebook, Twitter and subscriber button for easy sharing of functionality. Customers can also get the latest information easily. eSisterApparel Portal is link to other popular websites, portals and blogs.

- Website/portal-Introducing eSisterApparel Portal, purpose, what activities and services they are offering such as selling clothes make by the housewives.

- $\quad$ Face-to-face-The tutor deliver the tutorial workshop on sewing to the housewife face-to-face as well as virtually.

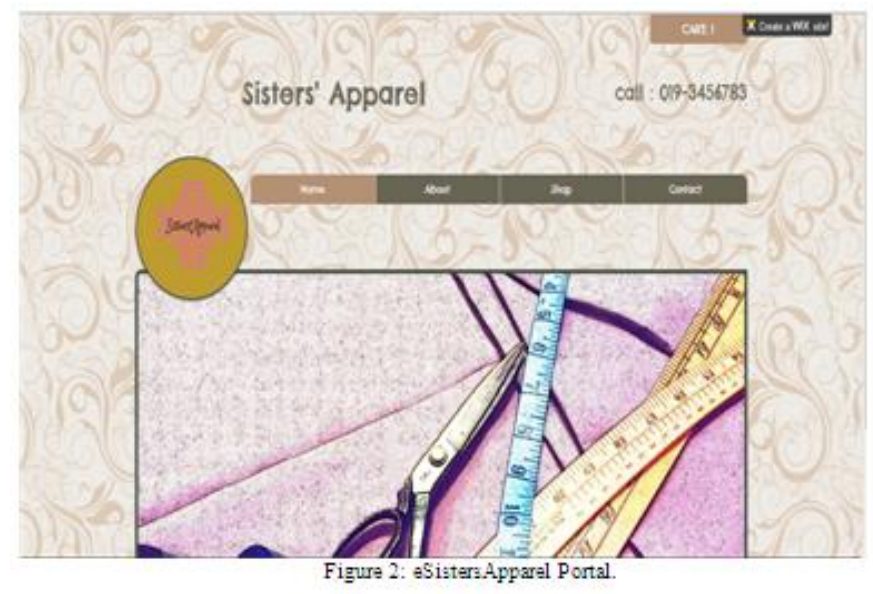

\section{Value Preposition}

- $\quad$ Sewing skill workshops and knowledge/tips to enhance sewing skill.

Sewing skill workshops to help and teach housewivesin sewing attractive, elegant and cheap clothes. Housewives are able to gain new knowledge and extra skills from these workshops. Moreover, the housewives can learn and enhance their sewing skill by making clothes such as Baju Kurung and blouse on their own.

- $\quad$ Clothes business and Income from selling clothes.

Housewives are able to engage in on-line clothes business where their market and reach is the world.

- $\quad$ Customer (shopper) customization.

Customers are able to customize and personalize their clothes design and preferences on-line. 


\section{Key Activities}

eSisterApparel Program provides the housewives free sewing machines which they can use to make clothes and earn their livelihood. Likewise, workshops and tutorials by experts are provided physically and virtually. eSisterApparel Portal creates an online presence, CoP, and marketplace for housewives so that they can sell their expertise, services and clothes.

\section{Key Resources}

- Key resources

Sewing machines from 1AZAM program - collaboration between government and SINGER. SINGER will get tax exception for its contributions in Corporate Social Responsibility (CSR) programs.

\section{- Unsewn cloths}

Unsewn cloths provided by interested companies such as KAMDAR. KAMDAR will get tax exception for its contributionsand commitment in Corporate Social Responsibility (CSR) programs.

\section{- Tutors}

The tutors are from IIUM Sewing Student Club, both the sewing teachers and students, who volunteered to teach and guide housewives to make elegant and attractive clothes. The volunteer students will get a star point and appreciation certification from IIUM as an extra curriculum.

\section{Key Partners based on the Quadruple Helix Model}

- Quadruple Helix Model (QHM), where a country's economic structure lies on four key actors namely: academia, industry, government, and citizen, and the economic growth generated poverty eradication by the clustering and concentration of talented and productive four actors.

- $\quad$ The Ministry of Women, Family and Community Development (1AZAM program) - AZAM Niaga scheme to generate income through small business.

- $\quad$ SINGER and PENASONIC - companies that collaborate with the government to provide the sewing machines.

- $\quad$ Volunteers from IIUM Sewing Student Club.

- $\quad$ KAMDAR - company providing the unsewn cloth.

\section{Cost Structure}

- $\quad$ Rental of cloud services and maintenance of eSisterApparel Portal

- Rental fees for sewing workshop

- $\quad$ Sewing tutorial contents and appliances

- Allowances for volunteers

\section{Revenue Streams}

- $\quad$ Provision from sponsors through government tax exemption of companies' contribution and involvement in eSisterApprel Program.

- $\quad$ Revenue from selling of clothes through eSisterApprel Portal.

- Subscription fees of affordable housewives.

- $\quad$ No fees for housewives from poor families.

\section{Future Work and Conclusion}

eSisterApprel Program shall initially offers "Baju Kurung"-related products. In future, it is proposed to develop more products such as sari, cheongsam, western dresses, and jeans. However, this offering shall depend on customers' demands. If this pilot implementation is successful in Sabah, eSisterApprel Program can be considered for national roll-out to benefit more poor families.And later would be world-wide implementation for poverty eradication. At the same time, continuous monitoring of eSisterApprel Program implementation and operations need to be conducted including visitations. This is to avoid embarrassing situations happening such as: "KUCHING: There is no denying that many 1Azam participants have sold off equipment given to them by the government to help them get out of poverty." (Borneo Post Online, 2014, 1Azam programme surpasses 7,500-participant target). Continuous skills upgrading, new and contemporary clothes designs offerings, international advertising and promotions need to be conducted, studied and coordinated.

In conclusion, this paper proposes eSisterApparel Program aim to raising the economic and social status of women especially of rural housewives in Sabah, Malaysia. The Quadruple Helix Model (QHM) implementation of eSisterApparel Program to be adapted by the Ministry of Women, Family and Community Development (MWFCD), where the country's economic structure lies on four key actors namely: government, 
academia, industry, and citizen. The economic growth and poverty eradication are done by the clustering and concentration of talented and productive 4 actors, spearheaded by MWFCD as the owner of 1AZAM program.

This eSisterApparel Program has the potential to reduce poverty in Sabah by providing these housewives with sewing skills, sewing machines, and eSisterApparel Portal in generating new sources of income. As the extent of rural poverty in Sabah is expected to be reduced and societal wellbeing to be enhanced through eSisterApparel Program, an added benefit is the minimization of the rural-urban migration process. This in turn will result in less pressure on government to make provision for additional spending on services such as education, provision of clean drinking water and adequate sewage disposal, housing, and health in urban areas as well as having to deal with a host of problems associated with overgrown cities and towns such as a higher incidence of crime and of shanty towns on the outskirts of these cities. The MWFCD needs to provide the leadership role for the success of eSisterApparel Program, implemented together with an effective and holistic change management program (Alyaa Ghani et. al, 2013).

\section{References}

[1]. 1Azam records 55.3\% cut in national poverty rate (2013). Retrieved Tuesday, March 04, 2014, 19:55 PM from: http://www.nst.com.my/latest/1azam-records-55-3pc-cut-in-national-poverty-rate-1.362321

[2]. 1Azam programme has created 4,300 women entrepreneurs (2013). Retrieved Tuesday, March 04, 2014, $20: 09$ PM from: http://www.nst.com.my/nation/general/1azam-programme-has-created-4-300-women-entrepreneurs-1.355274

[3]. 1Azam programme surpasses 7,500-participant target (January 9, 2014, Thursday). Retrieved Wednesday, March 12, 2014, 11:01 AM from: http://www.theborneopost.com/2014/01/09/1azam-programme-surpasses-7500-participant-target/

[4]. Alexander Osterwalder (2010). Business handbook for Visionaries, Game Changers, and Challengers”, John Wiley, New Jersey, USA.

[5]. Alyaa Ghanim, Fatima Munassar, Abdul Rahman Ahmad Dahlan (2013). "Project and Change Management Success Factors from Malaysian Government Departments and Agencies Perspective", IOSR Journal of Business and Management Vol. 11, No 2, pp. 3645

[6]. Ammy Amelia Faisal, Cutifa Safitri, Abdul Rahman Ahmad Dahlan (2013). "Value-Driven Approach for Project Success and Change Management in Malaysian Institutions of Higher Learning (IHL)", International Journal of Science and Research, Volume 2 Issue 6, June 2013

[7]. Blog of Ruang berkongsi “cerita" dan "ilmu jahitan" (2011). Retrieved Wednesday, March 12, 2014, 4:18 PM from: http://kedaijahitku-jahit.blogspot.com/p/kedai-jahit.html?m=1)

[8]. Burhan Saleh, Nalinee Ma-Key, Abdul Rahman Ahmad Dahlan, Rahmah Ahmad H.Osman (2013). "MyMukim2Cloud Collaborative System A Mosque Collaborative Network for Serving the Societal Needs in Malaysia", IEEE, 5th International Conference on Information and Communication Technology for the Muslim World 2013.

[9]. Cutifa Safitri, Ammy Amelia Faisal, Abdul Rahman Ahmad Dahlan (2013). "Success Factors and Change Management in Malaysian Institutions of Higher Learning (IHL)", International Journal of Science and Research, Volume 2 Issue 6, June 2013

[10]. Eric Schmidt and Jared Cohen (2013). “The New Digital Age: Reshaping the Future of People, Nations and Business”, Random House, Inc., New York.

[11]. EPU - Economic Planning Unit, Prime Minister's Department of Malaysia (2012). "Incidence of Poverty by Ethnicity, Strata and State, Malaysia, 1970-2012”. Retrieved March 04, 2014, from http://www.epu.gov.my/en/household-income-poverty

[12]. Fatima Munassar, Alyaa Ghanim, Abdul Rahman Ahmad Dahlan (2013). "Change Management and its Contribution to the Success of IT Project Implementation", International Journal of Information and Communication Technology Research, Volume 3 No. 4 , April 2013

[13]. Habiba Hamid, Nur Dini Khairuddin, Yousra Al-amodi, Abdul Rahman Ahmad Dahlan, Rahmah Ahmad H. Osman (2013). "MyMosqueNet2Cloud Collaborative System: A network of mosques towards eradicating poverty in Malaysia", American Academic \& Scholarly Research Journal, Vol. 5, No. 5, pp. 169-179.

[14]. Jenis Azam. Retrieved Wednesday, March 05, 2014, from: http://www.kpwkm.gov.my/jenis-azam

[15]. Jo Beall, Nazneen Kanji1 (1999). Households, Livelihoods and Urban Poverty Background Paper for the Escor. Commissioned Research on Urban. Development: Urban Governance, Partnership and Poverty.

[16]. Malathi Subramanian, (2007). Theory and Practice of E-Governance inIndia - A GenderPerspective.ICEGOV2007, December 1013, 2007, Macao

[17]. Minh Quang Dao, (2004) "Rural poverty in developing countries: an empirical analysis", Journal of Economic Studies, Vol. 31 ISS: 6 , pp. $500-508$

[18]. Ministry of Women, Family and Community Development (2012). Program 1Azam. Retrieved March 04, 2014, from: http://www.kpwkm.gov.my/nkra/lazam

[19]. PM: 1 Azam programme effective in eradicating poverty (2012). Retrieved March 04, 2014, 19:40 PM from: http://www.nst.com.my/nation/general/pm-1-azam-programme-effective-in-eradicating-poverty-1.94640

[20]. Prof. Dr. Mohd. Taib Hj. Dora (2011). Eradicate Urban Poverty in Malaysia through Entrepreneurship Strategies. International Journal of Humanities and Social Science, 1(20), Centre For Languages and Human Development, Universiti Teknikal Malaysia Melaka.

[21]. Sohag, K (2005). "Reducing Poverty through Zakat System": Research Paper written as Partial Fulfillment for the Course Eco 490Research Methodology, Submitted to Dr. Amir Hussaint, Adjunct Professor Department of Economics, East West University, retrieved March 04, 2014, from: http://www.scribd.com/doc/3176458/poverty-reduce-through-zakat-by-sohag 